\title{
Detecting Urban Land-Use and Land-Cover Changes in Mississauga Using Landsat TM Images
}

\author{
J. Li ${ }^{*}$ and H. M. Zhao \\ Department of Civil Engineering, Ryerson University, 350 Victoria Street, Toronto, Ontario M5B 2K3, Canada
}

\begin{abstract}
The City of Mississauga in Ontario has been experiencing a fast urban growth in the past two decades which has caused rapid loss of the valuable farm and open space land. Land-use and land-cover maps of the City were produced from Landsat TM images for 1985 and 1999, spanning a period of 14 years. Dramatic changes in land use and land cover have occurred, with loss of forest, cropland and water body to urban use. In particular, low-density urban use, which includes largely residential use, has increased by over 7.4\% between 1985 and 1999 . These land-use and land-cover changes have drastically altered the land surface characteristics. An analysis of Landsat TM images revealed an increase of $23.7 \mathrm{~km}^{2}$ of built-up area and a decrease of non-built $\left(23.2 \mathrm{~km}^{2}\right)$ and water area $\left(0.5 \mathrm{~km}^{2}\right)$. This paper illustrates the usefulness of a remote sensing approach for the urban change studies. According to the land-use and land-cover maps, four vegetation-impervious surface-soil (V-I-S) patterns of the city development were identified pertain to Mississauga's features.
\end{abstract}

Keywords: Change detection, land cover, land use, Landsat TM, remote sensing, urban mapping

\section{Introduction}

Today, about $47 \%$ of the world's population are living in urban areas and the number is expected to rise to $60 \%$ by 2030. Urban growth and sprawl have drastically altered the biophysical environment. Rapid urbanization has substantial influence on different aspects of the quality of life and brought an extensive attention of the researchers, urban planners, and landscape managers. In Canada, urbanization has been encouraged by the expansion or development of areas non-adjacent to the traditional downtown urban centres. These are areas of emerging residential, commercial, and industrial development, thus encroaching on the forested or agricultural hinterlands surrounding the city. Mississauga as a young city in Ontario, which was founded in 1974, had been experiencing a rapid urban expansion between the mid-1980s and the end of 1990s due to acceleration of economic growth and arrival of massive immigrants. According to Mississauga statistics demography data, the population of Mississauga had grown by 224,300 between 1986 and 1999 (City of Mississauga, 2003), equivalent to $60.9 \%$ of 1986 population of 368,100 . Mississauga is becoming the 6th largest city in Canada with a rapid population growth of 16,000 new residents per year. This urban growth has profound impacts on the available water resources, agricultural land, energy consuming distribution, and limited remaining space. A spatiotemporal analysis of growth patterns is essential in order to develop

\footnotetext{
* Corresponding author: junli@ryerson.ca
}

sufficient infrastructure to support the growth (Gluch, 2002). The development prospects of Mississauga would more rely on fully understanding its past and present pattern.

Current approaches to urban change monitoring generally involve ground surveys and interpretation of aerial photographs, but these are expensive and time-consuming and are very difficult to implement on a regular mapping basis. Thus, fast and low-cost methods that are capable of automatically mapping urban areas are desired. To this end, satellite remote sensing can be used to provide an objective and consistent view of urban areas in terms of required coverage and revisit reliability for this application (Lillesand et al., 2004). Satellite remote sensing has been employed as a valid and dispensable approach to monitor land-use and land-cover change due to its lower costs, easy-to-get and temporal consistency in the past three decades (Green et al., 1994; Ridd \& Liu, 1998; Ward et al., 2000; Yang \& Lo, 2002; Yang et al., 2003). Many studies and research literatures about these applications have been published by using multisensor, multispectral, and multitemporal satellite images combined with advanced mathematical methods and image process techniques, e.g., fuzzy classification (Zhang \& Foody, 2001), principal component analysis (Li \& Yeh, 1998), integration of remote sensing and geographic information systems (GIS) (Kam, 1995; Harris \& Ventura, 1995; Wang, 2001) and artificial neural network classifier (Civco, 1993; Augusteijn et al., 1995; Foody, 1996), texture analysis (Gluch, 2002), classification and regression trees (Ji \& Jensen, 1999; Yang et al., 2003), and sampling-based monitoring programme (Griffith et al., 2003). 
But until now, there is no consensus as to a single method/algorithm that is universally applicable (Yang et al., 2003).

The primary goal of this study was to develop an alternative approach to spatially quantify urban land-use and land-cover changes using satellite remote sensing data. Such $\mathrm{ab}$ approach needs to be objective, repeatable, and ideally, automated. In this paper, the land-use and land-cover change in the City of Mississauga for the period between 1985 and 1999 is reported. The purpose of this paper is to detect and reveal the urban growth from 1985 to 1999 in the city of Mississauga, an area of known high population growth in the past two decades using multi-dates Landsat TM images. An attempt was made to identify the "built" and "non-built" feature only, instead of attempting different types of urban use. V-I-S (Vegetation-Impervious Surface-Soil) model proposed by Ridd (1995) was also applied to identify the urban pattern of Mississauga.

\section{Study Area and Satellite Data}

The City of Mississauga, Ontario, is an ideal study area for this study because it has undergone rapid population growth in the past twenty years. The City covers almost $336.81 \mathrm{~km}^{2}$ (Industry Canada, 2003), with a population of approximately 600,000 (in 2000). It situated in the Peel Re-

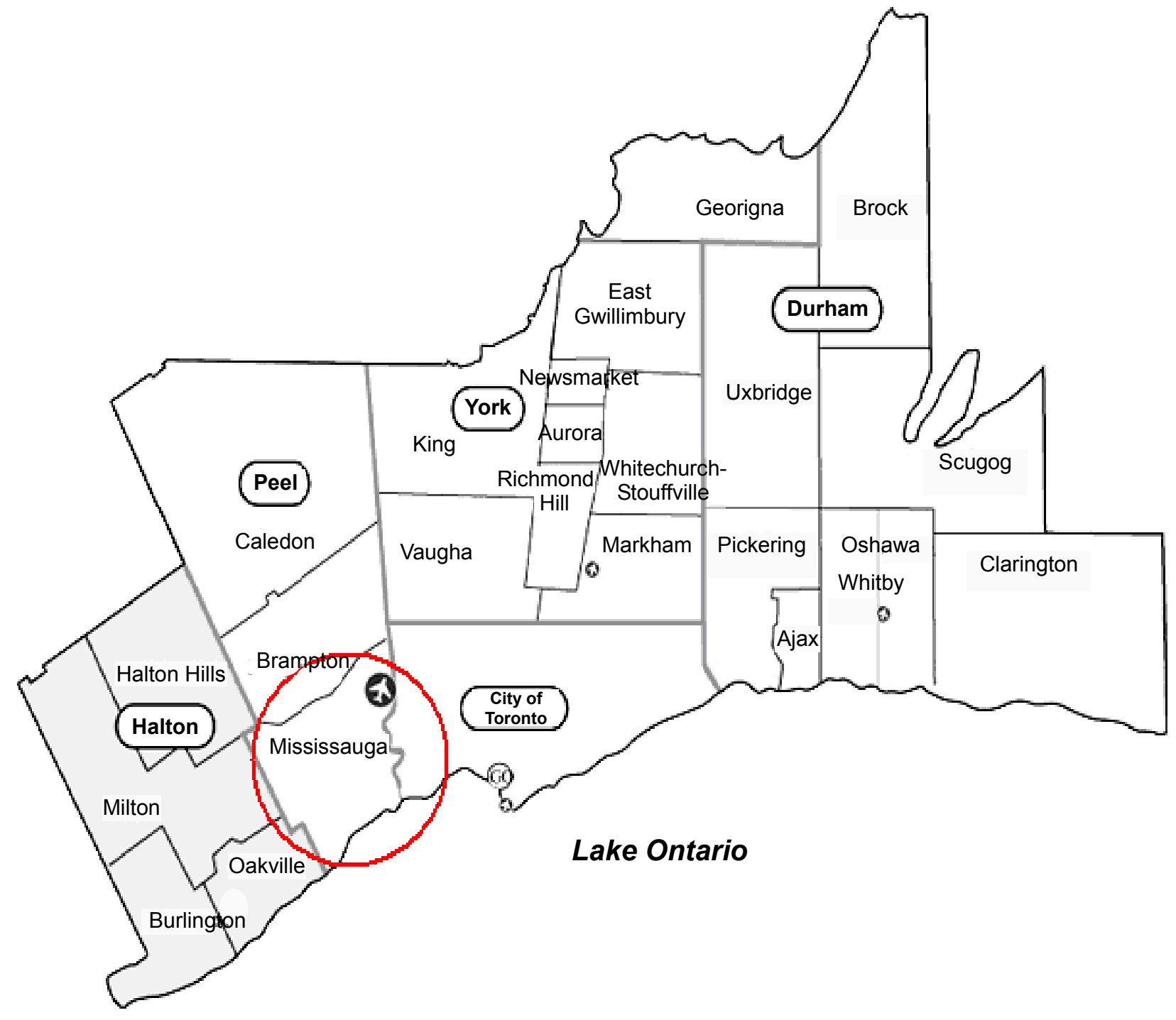

Figure 1. The location of the City of Mississauga in the Greater Toronto Area, Ontario. 


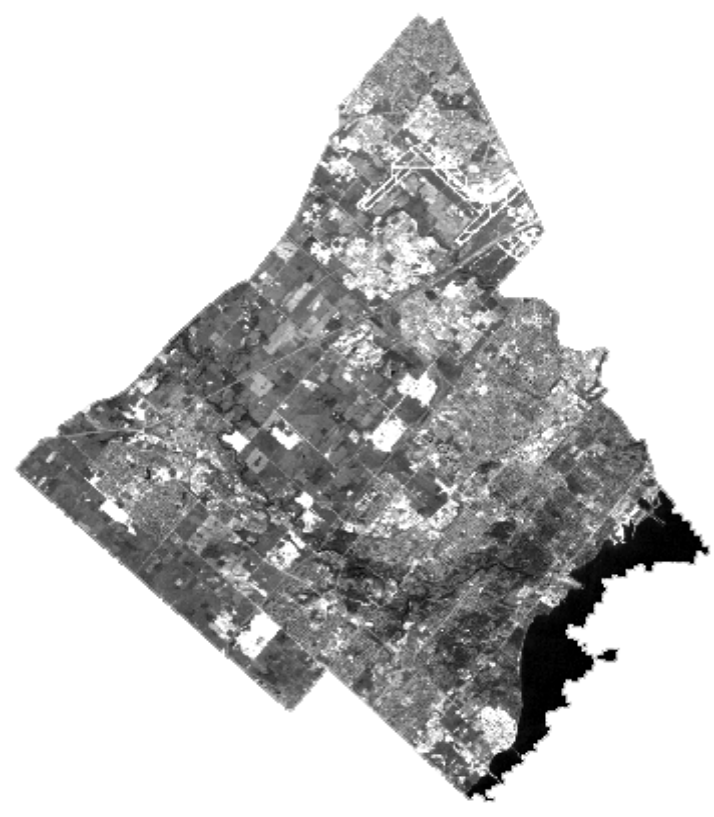

(a)

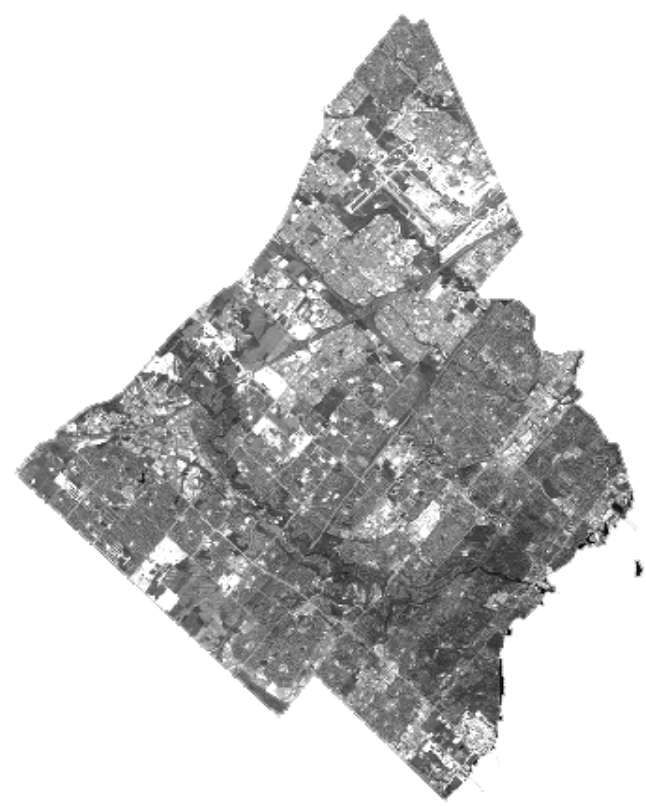

(b)

Figure 2. Satellite images covering the City of Mississauga (a) in 1985 with Landsat 5 TM and (b) in 1999 with Landsat 7 ETM+.

gion of the Greater Toronto Area (GTA) and next to the City of Toronto, the largest city in Canada, face to Lake Ontario. Canada's busiest airport, Lester B. Pearson International Airport, lies within its borders. The location of the study area is shown in Figure 1.

For this study, two cloud-free Landsat TM images covering the City of Mississauga acquired on September 20, 1985 and September 3, 1999 were employed (see Figure 2). Earlier fall is the preferred season for the Landsat scenes when the land is well covered by vegetation. The two TM images were georectified to the Universal Transverse Mercator (UTM) coordinate system (Zone 17), NAD83 horizontal datum and GRS 80 ellipsoid with coordinates in meters. The two images both were acquired in the same season (September) and already calibrated and geocoded except the resolution of pixels. The spatial resolution of 1985 TM image is $25 \mathrm{~m}$ while 1999 ETM+ image is $30 \mathrm{~m}$. Therefore, additional geometric rectification was performed to resample the two images to the spatial resolution of $30 \mathrm{~m}$. A first-order polynomial transformation and bilinear interpolation algorithm was applied to accurately match the images to the best available roads and landmarks. The resultant root-mean-square error (RMSE) of $3.29 \mathrm{~m}$ or less than 0.2 pixel values was obtained for both 1985 and 1999 images.

Reference data used in this study mainly include the $1 \mathrm{~m}$ resolution colour digital orthophotos of 1995 . The boundary vector data were used to subset the area of interesting (AOI), i.e., the City of Mississauga.

\section{Land-Use and Land-Cover Mapping Method}

In this study, the land-use and land-cover classification scheme, shown in Figure 3, was adopted with a main focus on differentiating between built-up and non-built areas.

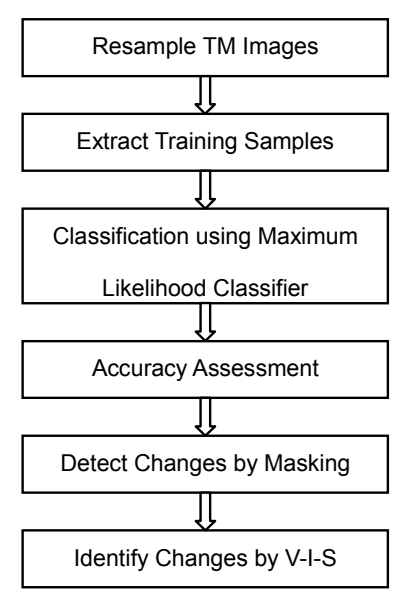

Figure 3. The land-use and land-cover classification scheme adopted in the study. 
For the sake of clarity, the "built-up" areas in this paper implicate urban uses or the areas covered by impervious urban materials, such as concrete, asphalt, and buildings, while the "non-built" areas refer to non-urban uses or more traces of nature features, like open space, forest, cropland, parks, golf courses and alike.

The classification-based (map-to-map) method of change-detection was performed in this study for its ability of detecting a full matrix of land-cover changes and identifying conversion from one land-cover to another (Yang et al., 2003). In the PC-based ERDAS Imagine V8.5 environment, the two TM images were classified by using a supervised approach known as Maximum Likelihood classifier (Lillesand et al., 2004) to generated land-use and land-cover maps. The mask-out technique was then applied to detect the urban change. The V-I-S pattern recognition was achieved through using reference data $(1 \mathrm{~m}$ resolution colour orthophotos and maps) and visual examination of the false-color composite of the classified Landsat TM images.

\section{Results and Discussion}

\subsection{Extraction of Training Samples}

For easy feature extraction and training sample identification, a spectral enhancement method was used to sharpen the images to make them more interpretable for naked eye. Based on the interpretation of different dates of ground truth maps and enhanced TM images, three basic feature classes, water, built-up and non-built, were identified and corresponding training samples were extracted. The utilities of signature alarms and contingency matrix were applied to evaluate if the signatures generated from training samples have accurately represented the classes to be identified. The contingency matrix was exhibited in Table 1. Generated signature results were shown as rows in the matrix and the reference data (ground truth) were shown in the columns. It was obvious that all the classified water points were real water pixels, but not all of the points classified as built and non-built were actually correct. This was because of intercrossing among built-up, non-built pixels and water pixels, such as low-density residential areas including many trees and green belts which belonged to non-urban uses; or some non-built areas may contain a single building and narrow roads; or bare soil may be characterized as the initial stage of new construction areas; or artificial ditches, out-door swimming pools, lake decks which are combined with built-up and water features, and so forth. Nonetheless, the correct rate of each training class was over $94 \%$ for both 1985 and 1999 TM scenes if we defined it as the percent of correct numbers of pixels over total classified pixels in the same class.

\subsection{Supervised Classification}

After satisfied signatures were obtained, the Maximum Likelihood classifier was applied to generate the land-use and land-cover maps with built-up and non-built classes according to the statistically-based parametric signatures which were used to define the desired classes. The classified land-use and land-cover maps of the City Mississauga are shown in Figure 4, in which the light-gray colour represents the built-up areas, the dark-gray colour for non-built areas and black colour for water areas (the Lake Ontario). The match was quite notable between the classified results and original images. Explicit increment of built-up areas could be easily recognized in the north, middle, and west part of the City of Mississauga.

Table 1. Contingency Matrix of Training Samples

\begin{tabular}{|c|c|c|c|c|}
\hline \multicolumn{5}{|c|}{ Mississauga 1985 Contingency Matrix } \\
\hline \multirow{2}{*}{$\begin{array}{l}\text { Generated } \\
\text { Signatures }\end{array}$} & \multicolumn{4}{|c|}{ Reference Data } \\
\hline & Water & Built-up & Non-built & Row Total \\
\hline Water & 2954 & 0 & 0 & 2954 \\
\hline Built-up & 46 & 3144 & 43 & 3233 \\
\hline Non-built & 0 & 56 & 2615 & 2671 \\
\hline $\begin{array}{l}\text { Column } \\
\text { Total }\end{array}$ & 3000 & 3200 & 2658 & 8758 \\
\hline \multicolumn{5}{|c|}{ Mississauga 1999 Contingency Matrix } \\
\hline \multirow{2}{*}{$\begin{array}{l}\text { Generated } \\
\text { Signatures }\end{array}$} & \multicolumn{4}{|c|}{ Reference Data } \\
\hline & Water & Built-up & Non-built & Row Total \\
\hline Water & 9863 & 0 & 0 & 9863 \\
\hline Built-up & 137 & 2127 & 0 & 2264 \\
\hline Non-built & 0 & 36 & 2456 & 2492 \\
\hline $\begin{array}{l}\text { Column } \\
\text { Total }\end{array}$ & 10000 & 2162 & 2456 & 14619 \\
\hline
\end{tabular}

\subsection{Accuracy Assessment of Classification}

Each of the land-use and land-cover map was compared to the reference data to assess the accuracy of the classification. The results of the accuracy assessment are presented in Table 2. In this study, 255 random sample points were generated, but only 96 and 104 sample points fell in the 1985 and 1999 classified map, respectively. The maps at the scale of $1: 25,000$ of the City of Mississauga in or close to the corresponding years and the $1 \mathrm{~m}$ resolution colour aerial orthophotos were employed as ground truth data to verify the classification accuracy. The overall classification accuracy was over 91\% and Kappa over 0.85 for either 1985 or 1999 classified map. Both producer's and user's accuracy were over $86 \%$. The user's accuracy was higher than the producer's accuracy in built-up areas, but the producer's accuracy was higher in non-built areas.

From the error matrix given in Table 3, all the points classified as water were actually water; the accuracy was $100 \%$ for both 1985 and 1999 classified maps. Only about 9\% of the points that belong to built-up were misclassified as non-built, or verse versa. These errors were accepted if considering the given $30 \mathrm{~m}$ spatial resolution of Landsat TM imagery. 




(a) 1985

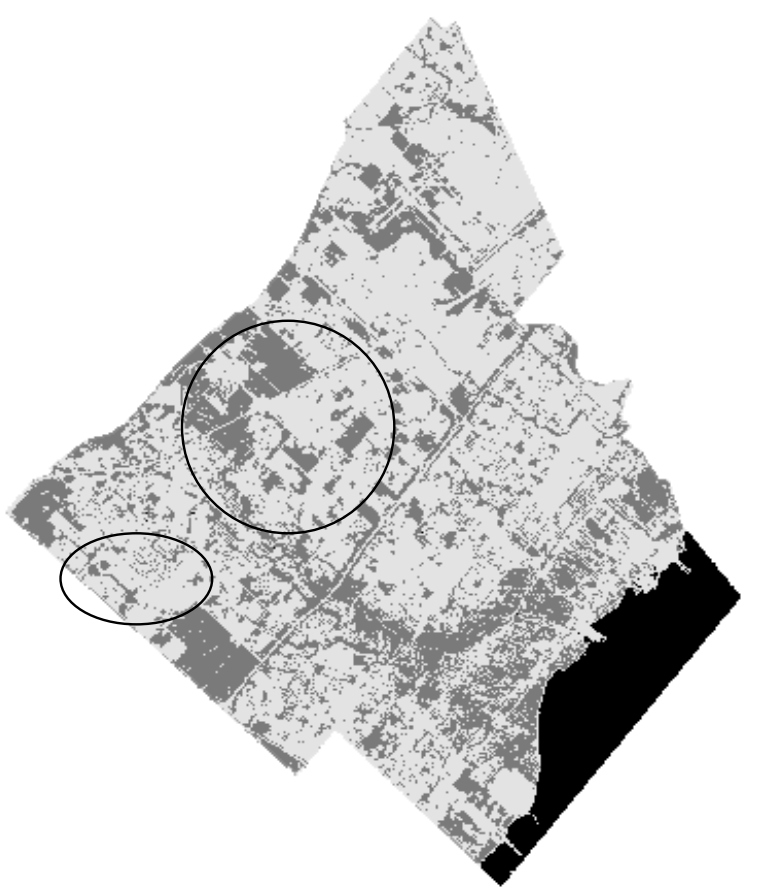

(b) 1999

Figure 4. Land-use and land-cover maps of the City of Mississauga as extracted from Landsat TM images.

Table 2. Classification Accuracy Assessment Report

\begin{tabular}{|c|c|c|c|c|c|c|}
\hline \multicolumn{7}{|c|}{1985 Classified Map } \\
\hline $\begin{array}{l}\text { Class } \\
\text { Name }\end{array}$ & $\begin{array}{l}\text { Reference } \\
\text { Total }\end{array}$ & $\begin{array}{l}\text { Classified } \\
\text { Total }\end{array}$ & $\begin{array}{l}\text { Number of } \\
\text { Correct }\end{array}$ & Producer's Accuracy & User's Accuracy & Kappa (к) \\
\hline Water & 9 & 9 & 9 & $100 \%$ & $100 \%$ & 1.00 \\
\hline Built-up & 51 & 49 & 46 & $90.2 \%$ & $93.88 \%$ & 0.79 \\
\hline Non-built & 36 & 38 & 33 & $91.67 \%$ & $86.84 \%$ & 0.87 \\
\hline $\begin{array}{l}\text { Column } \\
\text { Total }\end{array}$ & 96 & 96 & 88 & \multicolumn{2}{|c|}{ Overall classification accuracy $=91.67 \%$} & Overall $=0.85$ \\
\hline \multicolumn{7}{|c|}{1999 Classified Map } \\
\hline $\begin{array}{l}\text { Class } \\
\text { Name }\end{array}$ & $\begin{array}{l}\text { Reference } \\
\text { Total }\end{array}$ & $\begin{array}{l}\text { Classified } \\
\text { Total }\end{array}$ & $\begin{array}{l}\text { Number of } \\
\text { Correct }\end{array}$ & Producer's Accuracy & User's Accuracy & Kappa (к) \\
\hline Water & 11 & 11 & 11 & $100 \%$ & $100 \%$ & 1.00 \\
\hline Built-up & 62 & 63 & 59 & $87.1 \%$ & $90.0 \%$ & 0.86 \\
\hline Non-built & 31 & 30 & 27 & $95.16 \%$ & $93.65 \%$ & 0.84 \\
\hline $\begin{array}{l}\text { Column } \\
\text { Total }\end{array}$ & 104 & 104 & 97 & \multicolumn{2}{|c|}{ Overall classification accuracy $=93.27 \%$} & Overall $=0.85$ \\
\hline
\end{tabular}


Table 3. Classification Accuracy Detail Report

\begin{tabular}{|c|c|c|c|c|}
\hline \multicolumn{5}{|c|}{1985 Classification Error Matrix } \\
\hline \multirow{2}{*}{$\begin{array}{l}\text { Classified } \\
\text { Data }\end{array}$} & \multicolumn{4}{|c|}{ Reference Data } \\
\hline & Water & Built-up & Non-built & Row Total \\
\hline Water & 9 & 0 & 0 & 9 \\
\hline Built-up & 0 & 46 & 3 & 49 \\
\hline Non-built & 0 & 5 & 33 & 38 \\
\hline $\begin{array}{l}\text { Column } \\
\text { Total }\end{array}$ & 9 & 51 & 36 & 96 \\
\hline \multicolumn{5}{|c|}{1999 Classification Error Matrix } \\
\hline \multirow{2}{*}{$\begin{array}{l}\text { Classified } \\
\text { Data }\end{array}$} & \multicolumn{4}{|c|}{ Reference data } \\
\hline & Water & Built-up & Non-built & Row Total \\
\hline Water & 11 & 0 & 0 & 11 \\
\hline Built-up & 0 & 59 & 4 & 63 \\
\hline Non-built & 0 & 3 & 27 & 30 \\
\hline $\begin{array}{l}\text { Column } \\
\text { Total }\end{array}$ & 11 & 62 & 31 & 104 \\
\hline
\end{tabular}

\subsection{Urban Change Analysis}

The urban change analysis presented in this paper was based on the statistics extracted from the two land-use and land-cover maps of the City of Mississauga produced for the two dates: 20 September 1985 and 3 September 1999. The mask-out technique was applied to detect urban growth. The built-up and water areas in the 1985 TM scene were masked out from the 1999 TM scene (see Figure 5). The white colour represents newly increased urban use or built-up areas from 1985 to 1999 , while the black colour represents the mask of old built-up areas and water areas and the gray colour for non-built areas in 1999.

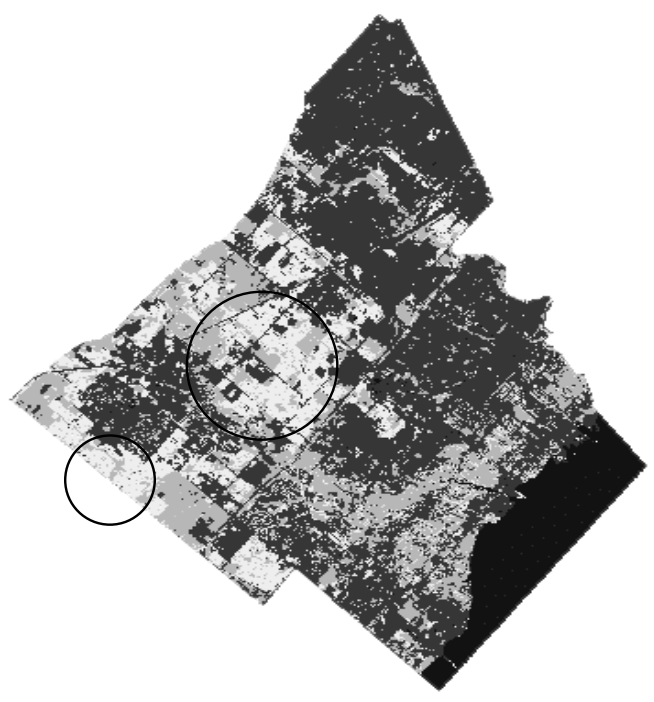

Figure 5. The land-use and land-cover change map of the City of Mississauga as extracted from Landsat TM data between1985 and 1999.
It is clearly revealed that the greatest change occurred in the west and upper-middle part of the City of Mississauga. Low-density urban use, which is mostly residential in nature, has increased its area spatially in 1999 compared to the 1995 scene. A lot of in-filling occurred within the low-density urban use areas. The increase in urban use is clearly at the expense of forest and cropland.

Same errors would be deducted from each other while overlaid two classified images, for example, old low-density residential areas classified as non-built areas, bare soil classified as construction areas (at the initial stage) and alike. This is true because same intercrossing errors in classification appeared in both 1985 and 1999 images. For big changes it may not be applicable in old built-up areas except that trees were getting higher density, more roads were built, more houses or buildings were reconstructed, and parks and grassland were well maintained. As in the non-built zones, same undeveloped status occurred as before. Only the new built-up areas could totally change the situation and was highlighted out.

Table 4 manifested the amount of actual changes in different land-use and land-cover features over the 14-year period. From 1985 to 1999 , a total area of $23.7 \mathrm{~km}^{2}$ areas had been built up as new residential zones, industrial areas, transition facilities, commercial centres, schools and such, equivalent to $7.4 \%$ of the total Mississauga area, and resulted in the identical area decrease of non-built and water space. Economic prosperity, population expansion, industrial development and urban growth are without any exception at the expensive of reduction of surplus utilizable space, such as of agricultural fields, forest, bare soil, wetland, etc. It was almost the rule of urbanization that surplus useful space had been diminished gradually instead of new construction. And according to this developing speed, Mississauga would exhaust its remainder space in another 14 years if we assumed that at least $20 \%$ vegetation area over total Mississauga area had to be kept for environmental needs.

Table 4. Substantial Growth of Built-up Areas in Mississauga from 1985 to $1999\left(\mathrm{~km}^{2}\right)$

\begin{tabular}{lllll}
\hline \multirow{4}{*}{ Year } & \multicolumn{4}{l}{ Land-use and Land-cover } \\
\cline { 2 - 5 } & Built-up & Non-built & Water & $\begin{array}{l}\text { Total } \\
\text { Area }\end{array}$ \\
\hline $\begin{array}{l}\text { 1985 Area } \\
\text { 1999 Area }\end{array}$ & 176.35 & 116.11 & 27.68 & 320.14 \\
$\begin{array}{l}\text { Difference } \\
\text { Between 1999 } \\
\text { and 1985 }\end{array}$ & 23.7 & -23.18 & -0.54 & 0.02 \\
$\begin{array}{l}\text { \% of the } \\
\text { Changes / } \\
\text { Total Area }\end{array}$ & $7.4 \%$ & $-7.24 \%$ & $-0.17 \%$ & $0.01 \%$ \\
\hline
\end{tabular}

A pixel size of $30 \mathrm{~m}$ is sufficient for land-use and land-cover classification at the macro or regional scale, but fails to provide detailed classification at the micro scale with satisfactory accuracy. It is expected that the use of images 


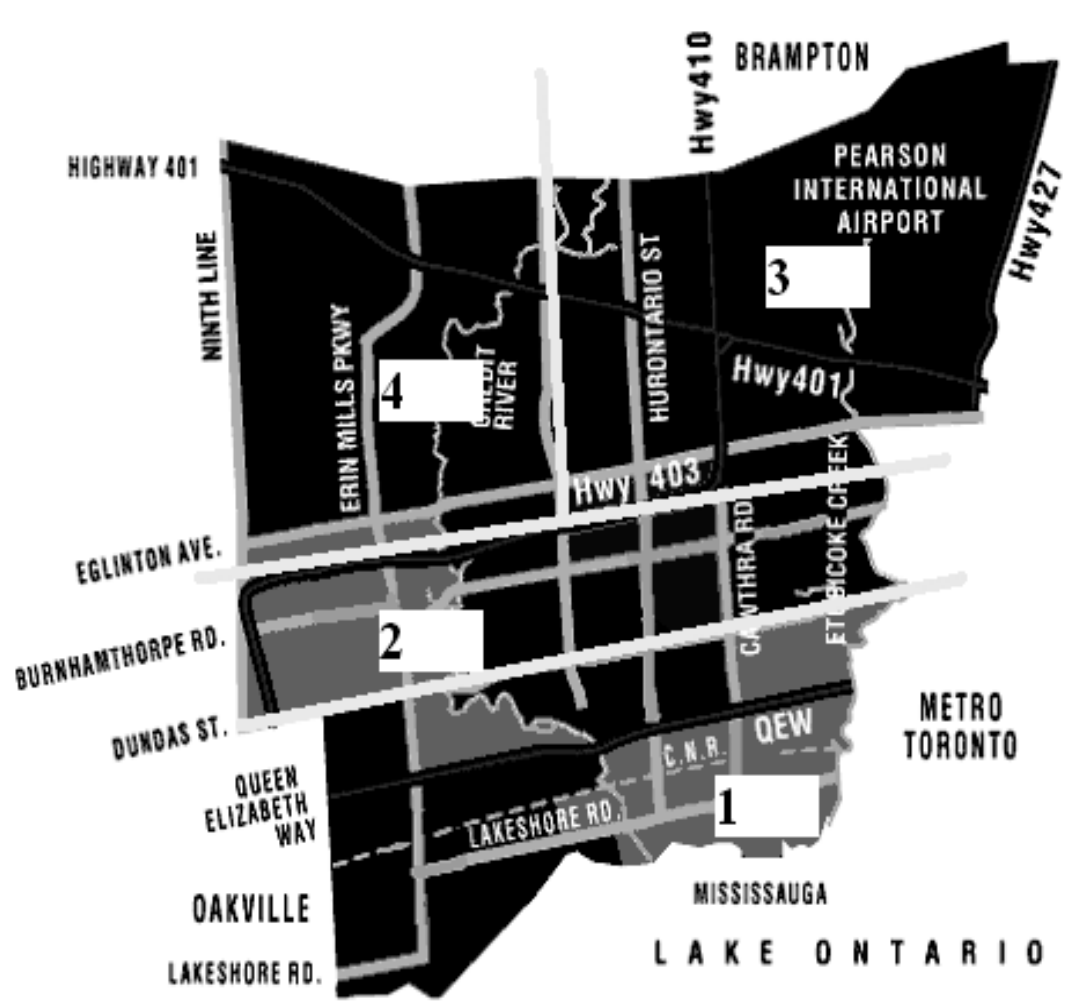

Figure 6. Four sections in the City of Mississauga.

acquired by recently launched high spatial resolution earth observation satellites, such as IKONOS, Quickbird, and OrbView-3, could improve the accuracy of detailed image classification and improve the change detection performance at the micro or local level. Between the 1985 and 1999, there was about $0.01 \%$ error of total area which stemmed from subset and resampling procedures.

\subsection{V-I-S Model Application}

In this study, for the purpose of the V-I-S model application as shown in Figure 6, the whole Mississauga area was further divided into four sections according to the world map and classification maps. Along the Dundas Road, Highway 403 and its prolongation, and Mavis Road, the four sections were segregated as South, Middle, Airport, and Northwest.

Table 5 enumerated the outline of each area. The description of characteristics of the four areas was basically upon the comparison between 1985 and 1999 situation.

In each section, randomly selected points using the same method as in accuracy assessment procedure, checked their spatial composition of vegetation-impervious surface-soil with referenced data, the V-I-S pattern could be drawn out based on the theory of Ridd (1995). The outcome was summa- rized in Table 6 , and corresponding meanings of each section was briefly described as well.

Section 1 was actually the old mature city district which featured with highest vegetation cover $(34.5 \%)$, lowest soil exposure (1.4\%) and least impervious surface (62.2\%) which meant the low-density of man-made trace and comparative stability from commercial expansion. By contrast, Section 2 marked with its reputation that high-density of man-made features $(78 \%)$ squeezed in crowded space at a sacrifice of sufficient green shelter $(20 \%) ; 1.8 \%$ soil surface indicated that limit surplus space was ongoing conversion and became a focus of attention. As to the rest two sections, Section 4 had a close feature as section 1 excluded its considerable soil exposure $(2.9 \%)$, it was an expanding residential area equipped with more meaning of forward-looking city style and environmental protection, such as preserve appropriate vegetation, matched with corresponding commercial centre, schools, parks, recreation centres, communities, and such. In Section 3, a fast pace of stretch was headlined with its highest soil exposure portion (4.1\%). Relatively higher impervious surface (72\%) and lower green cover (24\%) emphasized its modern industrial dominance. Fully developed transit facili- ties and system pledged its further growth and attracted more investment. 
Table 5. The Features of Four Sections in Mississauga, 1999

\begin{tabular}{lll}
\hline Section & Location & Features \\
\hline South & $\begin{array}{l}\text { South of Dundas Road, include south part of Erin Mill and } \\
\text { Cooksville, Port Credit district }\end{array}$ & $\begin{array}{l}\text { Mature city region, low-density residential area, concen- } \\
\text { trated parks and golf course, high-density trees and partial } \\
\text { existed industrial zone, face Lake Ontario, little utilizable } \\
\text { space }\end{array}$ \\
Middle & $\begin{array}{l}\text { South of Highway 403 and its prolongation, north of Dundas } \\
\text { Road, include north part of Erin Mill and Cooksville district }\end{array}$ & $\begin{array}{l}\text { City centre, high-density residential area, commercial centre, } \\
\text { schools, parks, little industrial area, limit surplus applicable } \\
\text { space }\end{array}$ \\
Airport & $\begin{array}{l}\text { North of Highway 403 and its prolongation, east of Mavis } \\
\text { Road, include Pearson international airport and its vicinity, } \\
\text { Malton district }\end{array}$ & $\begin{array}{l}\text { Except parts of residential area in north east corner and } \\
\text { south west corner, dominant industrial area and fully devel- } \\
\text { oped transportation facilities, considerable utilizable space }\end{array}$ \\
Northwest & $\begin{array}{l}\text { North of Highway 403 and west of Mavis Road, include } \\
\text { Meadowvale and Streetsville district, north Credit River } \\
\text { linger in middle }\end{array}$ & $\begin{array}{l}\text { Expanding residential area and corresponding commercial } \\
\text { centre, schools, parks, recreation centre, partial new built } \\
\text { industrial area, remarkable utilizable space }\end{array}$ \\
\hline
\end{tabular}

Table 6. V-I-S Composition of Four Divided Sections

\begin{tabular}{llllll}
\hline Section & V\% & I\% & S\% & Description & Total Sample Points \\
\hline South & 34.5 & 62.2 & 1.4 & Pertain to mature residential area, little conversion & 148 \\
Middle & 20.2 & 78.0 & 1.8 & City centre: some conversion & 109 \\
Airport & 24.0 & 72.0 & 4.1 & Developed and developing industrial area, significant conversion & 246 \\
Northwest & 32.9 & 64.2 & 2.9 & Undergoing residential area, considerable conversion & 173 \\
Mean & 27.9 & 69.1 & 2.6 & & \\
\hline
\end{tabular}

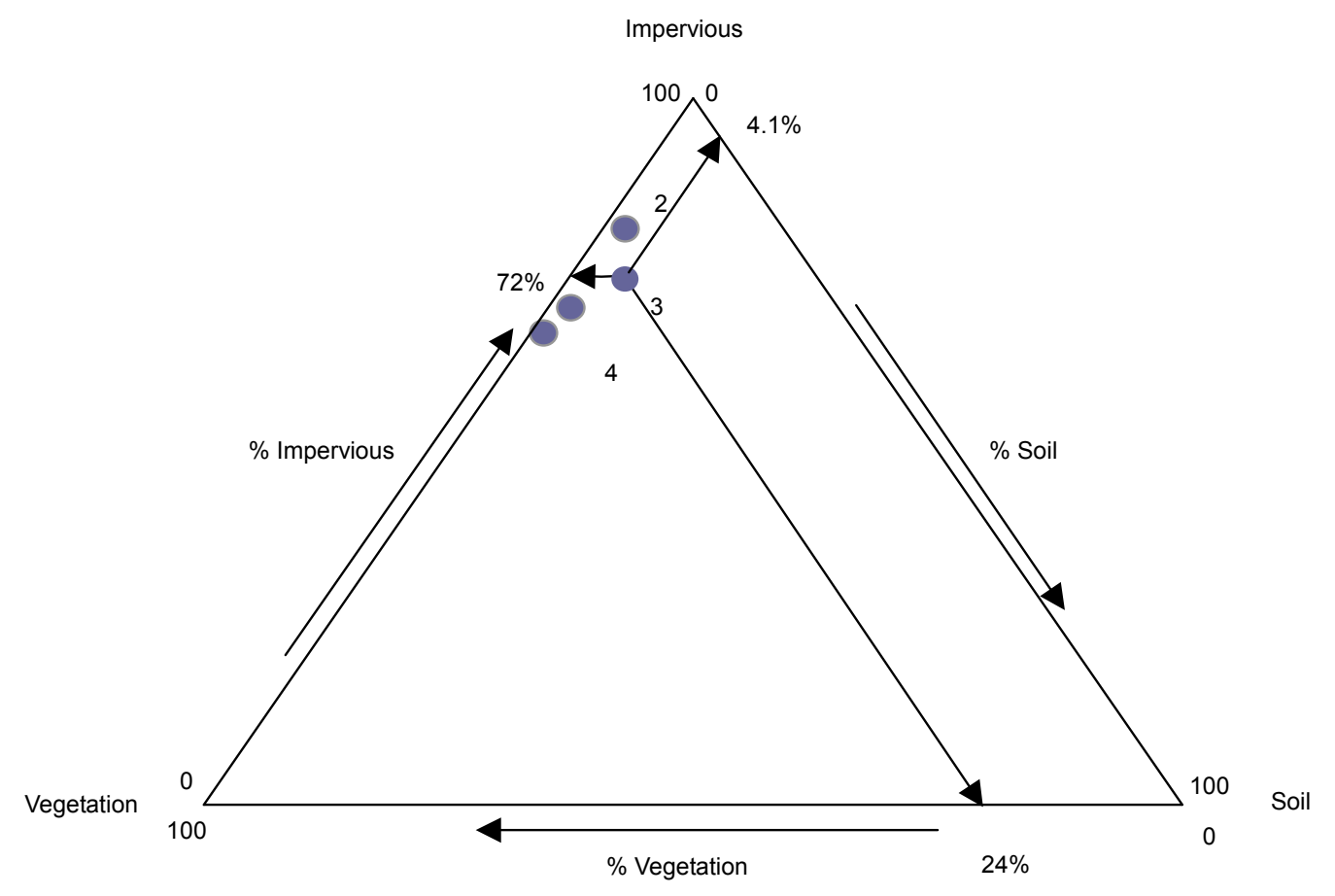

Figure 7. V-I-S diagram: 1-mature residential area, 2-city centre, 3-industrial dominance, and 4-growing residential area. 
Figure 7 shows the V-I-S patterns of the four sections. The four positions in V-I-S diagram were not perfect to match with the general urban features location presented by Ridd (1995), this was because the selected sections in this paper comprised relative large area and enclosed more features inside, but the patterns could declaim the city change format.

In addition, comparing the analysis results of both classification and V-I-S pattern obtained for this study with the Mississauga plan district land use world map (City of Mississauga, 2003), they match quite well. This positive outcome indicates that the employed methods and data were feasible and applicable in mapping land-use and land-cover changes of the City of Mississauga.

\section{Summary and Future Research}

The drastic land-use and land-cover changes in Mississauga over the past twenty years have resulted in the depletion of the vegetative cover and its replacement by such urban features as residential and commercial buildings, shopping malls, roads and parking lots. Two Landsat TM images acquired in 1985 and 1999 have been used to map and extract land-use and land-cover change of Mississauga using a supervised image classification approach with the support by reference data including $1 \mathrm{~m}$ spatial resolution colour aerial orthophotos and 1:25,000 scale maps to meet the standard of at least $85 \%$ in overall, producer's and user's accuracies. By using the V-I-S model, the urban patterns of the City of Mississauga have been established. The land-use and landcover maps revealed a great increase in low-density urban use at the expense cropland and open space over a 14-year period between 1985 and 1999. The urban change analysis results have demonstrated that $7.4 \%\left(23.7 \mathrm{~km}^{2}\right)$ of the Mississauga area had been built up during the 14-year interval; this is equivalent to the total decrease of non-built and water area. This urbanization has been further defined as four urban patterns based to their V-I-S composition. These outcomes will benefit for city planners and environmental managers to improve current deficiency and design their future blueprint.

Since the dramatic changes in land-use and land-cover have resulted in loss of vegetation covered land, thus they drastically alters the land surface characteristics. A time series of Landsat MSS and TM images will be further used to map and extract land-use and land-cover of the Greater Toronto Area for 1970s, 1980s, 1990s and 2000s in order to monitor the urban growth and sprawl which has altered the biophysical environment. The most noteworthy is the replacement of soil and vegetation with impervious urban materials (e.g. concrete, asphalt, and buildings), which affect the albedo and runoff characteristics of the land surface, thus significantly impacting the local and regional land-atmosphere energy exchange processes. Future research will focus on the study of urban heat-island through the use Landsat TM thermal band (Band 6) to extract surface temperatures for the past four decades. The surface tem- peratures and the spatial patterns of the normalized difference vegetation indices (NDVI) that can be extracted from Landsat MSS and TM images will be investi- gated for urban heat-island-effect studies.

Acknowledgments. This study carried out in the CFI-Virtual Environment Laboratory at Ryerson University was partially supported by the Natural Science and Engineering Research Council of Canada (NSERC) discovery grant and the Ryerson graduate scholarship. Technical assistance given by Des Rogan and Haibing Dong is greatly acknowledged.

\section{References}

Augusteijn, M.F., Clemens, L.E. and Shaw, K.A. (1995). Performance evaluation of texture measures for ground cover identification in satellite image by means of neural network classifier. IEEE Trans. Geosci. Remote Sens., 33(3), 616-626.

Civco, D.L. (1993). Artificial neural networks for land-cover classification and mapping. Int. J. Geogr. Inf. Syst., 7(2), 173-186.

City of Mississauga (2003). City of Mississauga Population and Employment 1991-2001. http://www.city.mississauga.on.ca/PLANBLDG/publications/ht $\mathrm{ml} /$ miss_growth_forecast.htm (accessed on 9 September 2003).

City of Mississauga (2003). Stats, Facts and Maps. http://www.city.mississauga.on.ca/PLANBLDG/online_maps/on line maps main.htm (accessed 9 September 2003).

City of Toronto (2003). The 1986, 1991 and 1996 Survey Summaries for the GTA-City of Mississauga-Demographic Characteristics. http://www.jpint.utoronto.ca/gta96/mun36.html (accessed 23 December 2003).

Foody, G.M. (1996). Relating the land-cover classification of mixed pixels to artificial neural network classification output. Photogramm. Eng. Remote Sens., 62(5), 491-499.

Gluch, R. (2002). Urban growth detection using texture analysis on merged Landsat TM and SPOT-P Data. Photogramm. Eng. Remote Sens., 68(12), 1283-1288.

Green, K., Kempka, D. and Lackey, L. (1994). Using remote sensing to detect and monitor land-cover and land-use change. Photogramm. Eng. Remote Sens., 60, 331-337.

Griffith, J.A., Stehman, S.V., Sohl, L. and Loveland, T.R. (2003). Detecting trends in landscape pattern metrics over a 20 -year period using a sampling-based monitoring programme. Int. J. Remote Sens., 24(1), 175-181.

Harris, P.M. and Ventura, S.J. (1995). The integration of geographic data with remotely sensed imagery to improve classification in an urban area. Photogramm. Eng. Remote Sens., 61, 993-998.

Industry Canada (2003). Community Demographics, Mississauga, Ontario.

http://broadband.gc.ca/demographic_servlet/community demographics/2872 (accessed 23 October 2003).

Ji, M.H. and Jensen, J.R. (1999). Effectiveness of subpixel analysis in detecting and quantifying urban impervious from Landsat TM imagery. Geocarto Int., 14(4), 31-39.

Kam, T.S. (1995). Integrating GIS and remote sensing techniques for urban land-cover and land-use analysis. Geocarto Int., 10, 39-49.

Li, X. and Yeh, A.G.O. (1998). Principal component analysis of stacked multi-temporal images for the monitoring of rapid urban expansion in the Pearl River Delta. Int. J. Remote Sens., 19(8), 1501-1518.

Lillesand, T.M., Kiefer, R.W. and Chipman, J.W. (2004). Remote Sensing and Image Interpretation, $5^{\text {th }}$ Edition, John Wiley \& Sons, New York, NY, USA, pp. 763.

Phinn, S., Stanford, M., Scarth, P., Murry, A.T. and Shyy, P.T. (2002). 
Monitoring the composition of urban environments based on the Vegetation-Impervious Surface-Soil (VIS) model by subpixel techniques. Int. J. Remote Sens., 23(20), 4131-4153.

Ridd, M.K. (1995). Exploring a V-I-S (Vegetation-Impervious Surface-Soil) model for urban ecosystem analysis through remote sensing: Comparative anatomy of cities. Int. J. Remote Sens., 16(12), 2165-2185.

Ridd, M.K. and Liu, J.J. (1998). A comparison of four algorithms for change detection in an urban environment. Remote Sens. Environ., 63, 95-100.

Ward, D., Phinn, S.R. and Mrrry, A.T. (2000). Monitoring growth in rapid urbanized areas using remotely sensed data. Prof. Geogr., 52(3), 371-386.
Yang, L., Xian, G., Klaver, J.M. and Deal, B. (2003). Urban land-cover change detection through sub-pixel imperviousness mapping using remotely sensed data. Photogramm. Eng. Remote Sens., 69(9), 1003-1010.

Yang, X., and Lo, C.P. (2002). Using a time series of satellite imagery to detect land use and land cover changes in Atlanta, Georgia metropolitan area. Int. J. Remote Sens., 9, 1775-1798.

Zhang, J. and Foody, G.M. (2001). Fully-fuzzy supervised classification of sub-urban land cover from remotely sensed imagery: Statistical and artificial neural network approach. Int. J. Remote Sens., 22(4), 615-628. 